\title{
Climate variability and causes: from the perspective of the Tharaka people of eastern Kenya
}

\author{
Charles W. Recha ${ }^{1^{*}} \mathbb{0}$, George L. Makokha ${ }^{2}$ and Chris A. Shisanya ${ }^{2}$
}

\begin{abstract}
The study assessed community understanding of climate variability in semi-arid Tharaka sub-county, Kenya. The study used four focus group discussions (FGD) $(N=48)$ and a household survey $(N=326)$ to obtain information from four agro-ecological zones (AEZs). The results were synthesized and descriptively presented. People in Tharaka sub-county are familiar with the term climate change and associate it with environmental degradation. There are, however, misconceptions and gaps in understanding the causes of climate change. There was a mismatch between community and individual perception of onset and cessation of rainfall_-evidence that analysis of the impact of climate change should take into account the scale of interaction. To improve climate change knowledge, there is a need for climate change education by scientific institutions - to provide information on local climatic conditions and global and regional drivers of climate change to local communities.
\end{abstract}

Keywords: Perception, Climate variability, Tharaka

\section{Background}

Construction of narratives regarding global warming and climate change has long been rooted in natural sciences-an attempt to understand the biophysical processes. This has involved monitoring of El Niño southern oscillation (ENSO) and other oceanic and atmospheric predictors of climate (Yasunaka and Hawana 2005; Hasternrath et al. 2004); and sectoral assessment of impacts of climate change (Fabeku and Okogbue 2014; Tonnang et al. 2010; Kundezewicz et al. 2008; Hansen and Indeje 2004). Biophysical assessment of global warming has led to improvement in the understanding of interactions between atmosphere, sea, and land surfaces; advances in modeling and prediction of the global climate system. This has laid the foundation for adaptation (Hansen 2005). Indeed, the idea of climate change has been universalized-generalized (Hulme 2008). The generalization of climate change may apply to the physical

\footnotetext{
*Correspondence: charles.recha@egerton.ac.ke

1 Department of Geography, Egerton University, P. O. Box 536,

Egerton 20115, Kenya

Full list of author information is available at the end of the article
}

drivers (such as El Niño southern oscillation), globalscale impacts (such as sea level rise), and on global benefits of mitigation to climate change (Locatelli 2011). Although universalization is in line with globalization, it fails to account for the geographical diversity of the physical and human environments. Understanding of climate change can be improved when the physical dimensions are allowed to be interpreted by their cultural meanings.

There have been efforts to highlight the magnitude and impacts of climate change at different geographical scales in the different sectors of human interest; notably agriculture, water, economics, health among others. Given the relative lack of data especially in developing countries, research on impact of climate change has been at macro-levels with heavy reliance on models (Washington et al. 2006; Hansen 2005). Climate change modeling has often been associated with uncertainties. These limitations, identified as early as in the 1980s and 1990s led to calls for research on cultural adaptation and climate change to give useful insights (Vedwan and Rhoades 2001). This has prompted a re-examination of climate change needs in order to include the contribution of interpretative humanities and social sciences (Hulme 
2008). This re-examination should include attempts to reconnect communities in a local setting with climate, and provide an understanding of what climate change means to people in specific cultural and geographical environments.

There are studies that have sought to establish a relationship between actual impacts or changes in climate and people's perception of these changes. The findings yield varied results. For instance, Adimassu et al. (2014) and Becken et al. (2013) established that communities are not always scientifically accurate in their assessment of climate change. Thus, there are cases where climate change and its associated impacts are exaggerated or underestimated. In Gladstone South Africa, Gandure et al. (2013) found mixed results; farmers' perception of high rainfall variability was supported by meteorological data while their perception of rainfall onset was at variance with meteorological data. The implication is that awareness of climate change impact if not verified with empirical data, can lead to misinformation. On the other hand, Howe et al. (2014) established that in India, respondents who indicated annual rainfall changes (increasing or decreasing) were located in parts of India that corresponded with their perceived changes. There are other studies that have examined the influence of socio-economic factors on the perception of climate change. For instance, Opiyo et al. (2016) established that gender, livestock ownership, and access to extension services influenced the perception of climate change. Maddison (2007) found that experience (years spent in farming) influenced farmer perceptions of climate change. These findings suggest that perception of climate change assumes a spatial scale and will depend on socioeconomic attributes of the population under study.

Despite the shortcomings, perception studies can bring to the fore community understanding of local environment and climate (Becken et al. 2013). Kashaigili et al. (2014) and $\mathrm{Li}$ (2015) examined perception of climate change and variability among peri-urban and rural communities in Tanzania and China, respectively. Whereas the approaches of Kashaigili et al. (2014) and Li (2015) seek to bring out variation in climate change perception based on socio-economic environment, there is a need for perception studies among marginal groups-especially in arid and semi-arid lands. Lorenzoni and Pidgeon (2006) investigated the public conceptualization of climate change on a regional scale-highlighting differences in the USA and Europe. Similarly, Leiserowitz (2005) examined risk perceptions and connotative meanings of global warming among Americans (in the USA). These findings serve to demonstrate how economic benefits and influence of the media shape public perceptions on impacts of climate change. For developing countries such as Kenya, climate change often connotes economic losses and human suffering-necessitating public perception of impacts of climate change.

Perception studies on climate change make valuable contributions because they provide information on local climatic condition and knowledge which can be factored in empirical studies. This study is premised on the need for knowledge of public attitude, beliefs, and perceptions in complementing biophysical research in climate change in Kenya (Republic of Kenya 2010a). According to Leiserowitz (2005), public risk perceptions are critical components of the socio-political context within which policymakers operate. In this study, we postulate that understanding local perception of climate change indicators and causes is critical to arriving at understanding the choice of community responses.

\section{Methods}

\section{Study area}

Tharaka sub-county is found in Tharaka-Nithi County and covers an area of $1569.5 \mathrm{~km}^{2}$ and a population of 175,905 (Republic of Kenya 2010b). Tharaka sub-county is predominantly inhabited by Tharaka people-a subgroup of the larger Meru ethnic group (Smucker and Wisner 2008). The sub-county has four agro-ecological zones (AEZs): lower midland (LM)4, lower midland (LM)5, intermediate lowland (IL)5, and intermediate lowland (IL)6 (Jaetzold et al. 2007). Agropastoralism is the main livelihood support system. Tharaka sub-county is located on the Eastern side of Mount Kenya (Fig. 1). Tharaka has a bi-modal rainfall-March-May (MAM) and October-December (OND) (commonly known as 'long rains' and 'short rains', respectively). As a semi-arid sub-county, rainfall is highly variable (Recha et al. 2012) and this affects the community's livelihood system. The climatology of Tharaka sub-county, like the larger East Africa, is influenced by large-scale systems such as the inter tropical convergence zone (ITCZ), ENSO, and sea surface temperatures of the Pacific, Indian, and Atlantic Oceans (Mutai et al. 1998). Tharaka sub-county as one of the semi-arid lands in Kenya has a high incidence of poverty and frequently suffers from low and erratic rainfall (Orindi and Ochieng 2005). The net effect has been overreliance on food relief from government and development partners. Since independence, the people of Tharaka have remained poor and lack basic amenities such as water, adequate schools, tarmac roads, and electricity. This has engrained a feeling of marginalization (Mworia and Ndiku 2012) that has bred hostility to neighboring communities. Climate change and variability has made the situation worse. There are on-going efforts to support climate change adaptation, along with devolution which has brought development and government 


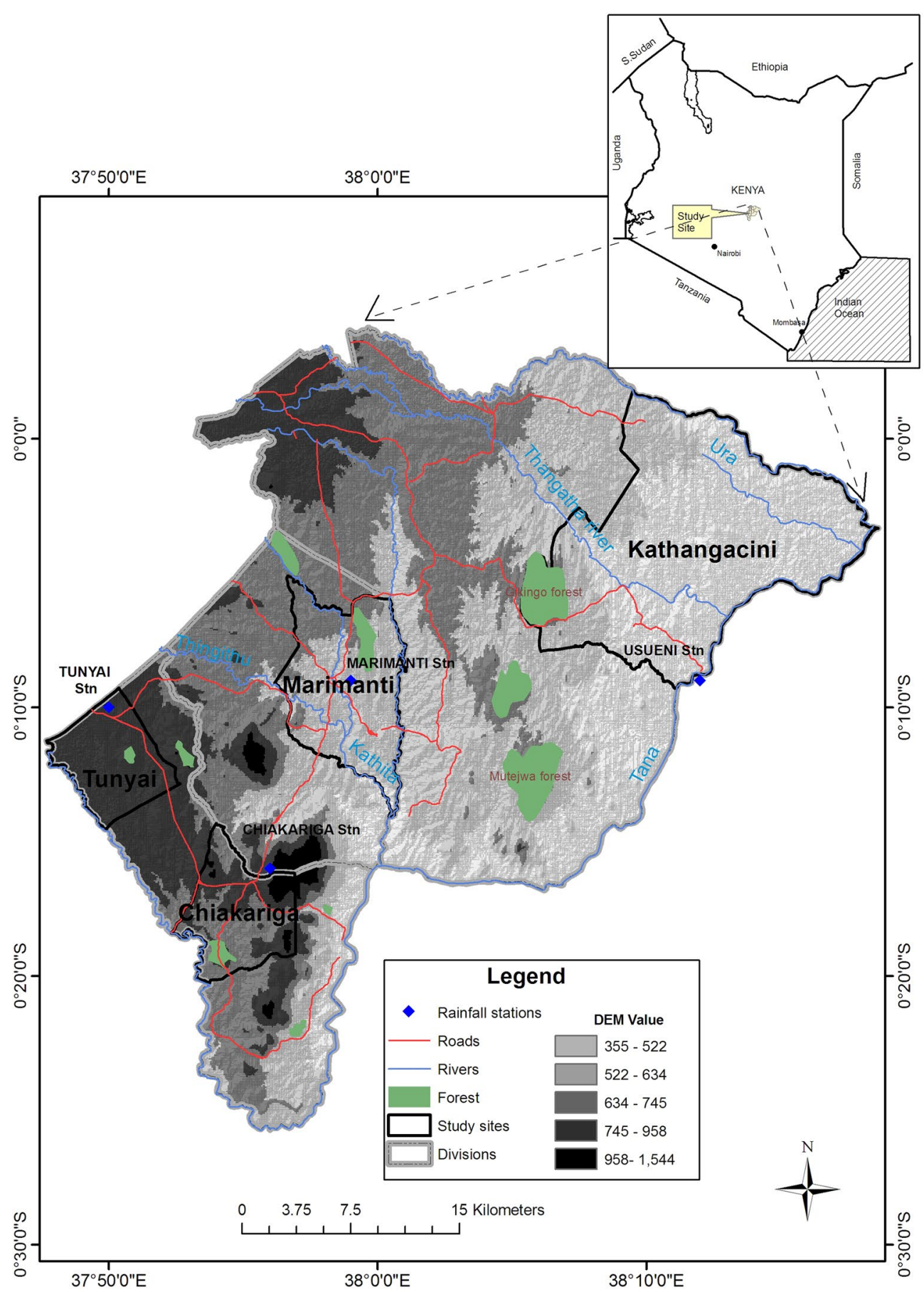

Fig. 1 Map of study area showing sampled administrative units

closer to people of Tharaka. But a meaningful diagnosis of the problem of climate change and variability, like other problems in Tharaka sub-county, depends on perception. Thus, understanding of and responses to climate change significantly depend on how the people perceive patterns and causes of climate change.

\section{Data collection}

The study utilized two sets of data: focus group discussions (FGD) and household survey. The target study sites were Tunyai (LM4), Chiakariga (LM5), Marimanti (IL5), and Kathangacini (IL6) divisions (3rd lowest administrative unit in Kenya). Selection of study sites was based on 
agro-ecological zones in Tharaka sub-county (Jaetzold et al. 2007). The rationale was to try as much as possible to include the diversity of environmental and climatic conditions that people experience (This approach was also used by Becken et al. 2013). However, culture was assumed to be a constant since majority of the people in Tharaka sub-county are of the Tharaka tribe. The first set of data was collected through FGDs which were conducted in each of the four study sites as shown in Table 1 (also see Fig. 1).

A total of forty-eight (48) respondents were purposively sampled to participate in the FGD (Additional files 1 and 2). Sampling of participants was carried out with the assistance of field monitors working for the Department of Arid Lands in Tharaka sub-county. Selection of FGD participants was based on field monitors' knowledge of their socio-economic well-being (age, education, gender, and income) and participation in social programmes in the community. Open-ended questions were used to seek information from FGD participants (Additional file 3). According to Becken et al. (2013) open-ended questions facilitate spontaneous opinions and avoid restrictions-an attribute critical for this study. The discussions were facilitated in Swahili-a national language widely spoken in Kenya. Where necessary, field monitors (themselves of a Tharaka tribe) would translate questions. This was however not common as most respondents could express themselves in Swahili. In conducting FGDs, reference was made to a twenty-year period (climate change). Thus although respondents' age ranged from 18 years and above, the specific question of 'has climate changed in your locality in the past 20 years?' was mainly directed to participants aged 36 years and above. The purpose of FGD was to generate qualitative data to provide information on community understanding of climate change and variability.

Like FGDs, household respondents were drawn from across the four main agro-ecological zones. A total of 326 respondents were sampled and interviewed across the four study sites. Selection of respondents was informed by the number of household population at sub-location level as guided by the sub-county development officer in

Table 1 Sample population by study sites

\begin{tabular}{|c|c|c|c|}
\hline \multirow{2}{*}{$\begin{array}{l}\text { Administrative } \\
\text { division }\end{array}$} & \multirow{2}{*}{$\begin{array}{l}\text { Agro-ecological } \\
\text { zone (AEZs) }\end{array}$} & \multicolumn{2}{|c|}{ Sample population (total) } \\
\hline & & Households & FGD participants \\
\hline Kathangacini & IL6 & 58 & 12 \\
\hline Marimanti & IL5 & 92 & 11 \\
\hline Tunyai & LM4 & 78 & 13 \\
\hline Chiakariga & LM5 & 98 & 12 \\
\hline Total & & 326 & 48 \\
\hline
\end{tabular}

Tharaka. In each of the four study sites, $5 \%$ of the households were selected for interview using the method of Kajembe et al. (2005). Household survey provided data on perceived variations of climate indices. The targeted climate indices were frequency of extreme events, and changes in onset and cessation of the two main growing seasons-MAM and OND. Household survey results were used to validate the findings of FGDs. It is instructive to note that effort was made to ensure that respondents involved in the household survey did not participate in the FGD to avoid potential undue advantage of the nature of the study.

\section{Data analysis}

Household survey data were coded, entered, and descriptively analyzed using the statistical package for social scientists (SPSS) version 11.5. Deliberations of FGDs were recorded and subjected to interpretations. It is instructive to note that in this study, the first day of rainfall onset for MAM and OND seasons were considered as March 1st and October 1st, respectively. For rainfall cessation, the last days were considered as May 31st and January 31st for MAM and October-November-December-January (ONDJ) seasons, respectively. Even though most of the rain is received during the OND season, there is usually a spill over effect into January (Shisanya 1996). Further, very often seasonal climate forecasts by the Kenya Meteorological forecast have occasionally indicated cessation of the short rains extending into January (http:// www.meteo.go.ke). On these two accounts, January was therefore considered as the rainfall cessation month for the short rain season. The demarcation of these seasons was useful in the determination of the perceived dates of onset and cessation of rainfall by respondents.

\section{Results and discussion}

The opinion that rainfall patterns had changed in Tharaka sub-county was virtually universal (98\%). This response was strong across agro-ecological zones, gender, and age (reference made to persons aged 36 years and above. These persons are considered to be able to recall events of the past 20 years). The main indicators of change (of rainfall pattern) were increase in frequency of extreme events (specifically prolonged drought) (43\%), change in rainfall amount (43\%), change in dates of onset (5\%), and reduced growing season (5\%) (Fig. 2). A higher number of respondents in agro-ecological zones IL6 (43\%) and IL5 $(48 \%)$ considered change in rainfall amount the main evidence of change in climate patterns. While a higher number of respondents in agro-ecological zone LM4 (48\%) and agro-ecological zone LM5 (38\%) regarded extreme events such as droughts and floods as evidence of change in climate variability. 


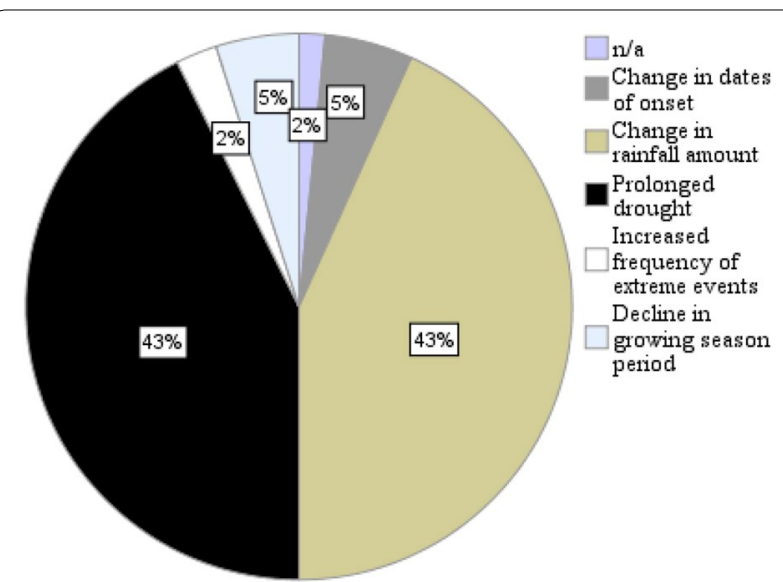

Fig. 2 Perceived evidence of climate change in Tharaka sub-county

Tharaka people's perception is in line with long-term empirical analysis of rainfall which shows that OND and annual rainfall have been persistently below normal (Recha et al. 2012). Study findings relate with those of Sanchez-Cortes and Chavero (2011) and Howe et al. (2014) where communities in Mexico and India, respectively, perceived a decrease in rainfall amount and duration. Variations in perception by agro-ecological zones can be attributed to diversity in livelihoods (Gioto et al. 2016). Agro-ecological zones IL5 and IL6 are characterized by marginal mixed farming of livestock and droughttolerant crops (millet and green gram). Thus, insufficient rainfall amount to support cropping may lead to dependency on livestock. On the other hand agro-ecological zones LM4 and LM5 are mixed farming and rain-fed cropping livelihood zones, respectively. For these livelihood zones, frequency of extreme events-especially drought, severely affects dairy farming and crop farming (maize and beans). Note that livelihood activities in LM4 and LM5 demand more water than in IL5 and IL6.

FGD participants were asked to describe the terms climate, weather, climate variability, and climate change. They were further asked to describe the rainfall regime of their area and outline consequences of climate variability in their communities. An attempt to get the word for weather and climate in the local dialect-Kitharaka, proved futile. This was despite having elderly participants of over 75 years of age. Climate was described as variations in wind, temperature, or rainfall. Climate was further understood as the annual change of weather. According to participants, seasons of high and low rainfall, low and high temperatures, represent climate.

Climate variability was seen more as variations that bring about seasons. Participants described nthano (March-May rainfall season), muratho (OctoberDecember rainfall season), thano (August-October dry period), and kiathu (February-March dry period). Respondents further referred to climate variability as the annual variation of seasonal rainfall. From the findings, the people of Tharaka have four seasons-contrary to the long-standing narrative that Kenya has two rainfall seasons-MAM and OND. In Tharaka, there are two rainfall seasons and two dry seasons. Leonard et al. (2013) observed that knowledge of seasons and sub-seasons form the hierarchy for which all other traditional ecological knowledge within the season calendar is ordered. Among the Tharaka, knowledge of seasonality heavily influences cropping system, grazing patterns, and livelihood support adaptation strategies to climate variability. According to Sanchez-Cortes and Chavero (2011) knowledge of how people experience climate variability is essential, taking into account their local calendar of agricultural activities. To the Tharaka people, knowledge of the quantity of rainfall received in each season is an important guide to their livelihood support system.

According to FGD participants, rainfall onset and cessation have changed, and within-season rainfall distribution has become irregular when compared to the past 20 years. For instance, in the past, onsets of MAM and OND seasonal rains was in early March and mid October, respectively. While cessation for MAM and OND occurred at end of May and early January, respectively. Respondents claimed that at present, onset is in early April and November for MAM and OND growing seasons, respectively. Rainfall cessation is said to occur in the last week of April and mid-December for MAM and OND growing seasons. The consequence of change in onset and cessation dates was a shift from maize to sorghum and millet farming-particularly in the drier IL6 (Kathangacini). The observation suggests that rainfall variability has altered the cropping system. Early onsets in the past were always associated with high crop yields. This is no longer the case as growing seasons have become shorter and the within-season distribution has become poor. The reduced amount of rainfall has also contributed to reduced water levels in streams, especially in LM4 (Tunyai).

But community perception of changes in onset and cessation was at variance with household survey. A majority of households opined that onset of MAM and OND rainfall seasons was mainly in the 2nd week of March and October, respectively. For the MAM season, 34 and 49\% of respondents observed that onset was realized in the 2nd and 3rd weeks of March, respectively. Onset of OND season was reported to occur in the 2nd week (28\%) and 3rd week (51\%) of October. To a majority of respondents cessation usually occurred in the 4th week of May (35\%) during MAM and the 2nd week of January (52\%) during OND. In a related study using historical rainfall data, 
Recha et al. (2012) established that mean rainfall onset for MAM and OND was between 21st and 25th of March and October, respectively; while mean rainfall cessation occur on May 16-20th for MAM season and January 5-10th for ONDJ season. Thus, results of historical rainfall data are in agreement with household survey but differ with FGD results.

Variations in perception and historical data analysis of climate variability were also reported in Adimassu et al. (2014) where farmers perceived a decreasing rainfall amount and crop yield, contrary to historical data. The differing view of households and FGD on onset and cessation highlights a fundamental issue in understanding climate change and variability; that there are differences in group and individual perception of climate change. This can potentially lead to a wrong diagnosis of the problem of climate change. Such variation reinforces the need to accurately collect rainfall data (and other weather elements) for community use in decision making instead of relying on perceptions. Basic skills in climate data collection, analysis, and descriptive presentation among community members would improve the understanding of climate.

The term climate change was very familiar to participants as they had heard it from the radio and extension officers. There was unanimity in all the four FGDs that there was climate change in Tharaka sub-county. Participants associated climate change with change in weather elements in a specified period. To illustrate climate change, participants gave an example of how in the past temperatures were relatively low compared to the present. Participants associated climate change with charcoal burning and industrial pollution which are 'tearing the sky apart.' Climate change, especially warm temperatures was attributed to deforestation.

FGD results indicated that the terms weather and climate are synonymous in Kitharaka. Lack of differentiation of these terms poses the risk of failing to tap into climate as a resource. This can be corrected by educating communities on quantitative characteristics of climate and generally providing facts of their locality. Community understanding of climate variability and change had similarity with standard definitions such as that given by van de Steeg et al. (2009). Participants closely linked climate change and variability to environmental degradation. Deforestation and destruction of wetlands to create land for human settlement were cited as lead causes of climate change and variability. Other causes of climate change and variability cited by respondents were pollution of major oceans (through ship transportation), use of pesticides and insecticides (as a result of land surface run-off), and God's plan.
The correct identification of deforestation, wetland destruction, and industrial pollution as causes of climate change and variability can be seen as an outcome of increased awareness and can be used to serve as a basis to encourage collective learning on land degradation as observed by Tscharkert (2007). The observation that human activities are 'tearing the sky apart' was interpreted to mean the depletion of the ozone layer. In related studies of Silva et al. (2014), Gandure et al. (2013), Mubaya et al. (2012), and Byg and Salick (2009), communities were found to associate climate change and variability to God's retribution and human activities such mining, car emissions, deforestation, recreational fishing, tourism, and mining. It is evident from the findings that Tharaka people's perception of the causes of climate change and variability mirrors that of other communities. However, there were misconception and gaps in understanding the causes of climate change and variability. To associate climate change and variability with pollution of the ocean and use of pesticides demonstrates a gap in understanding the role of oceans in climate change and variability. Indeed $\mathrm{Li}$ (2015) also established that the Chinese rural community had poor knowledge of causes and impacts of climate change science. Provision of basic information on the role of the inter tropical convergence zone, monsoon trade winds, and sea surface temperatures on East Africa climatology (Seleshi and Zanke 2004; Camberlin and Okoola 2003) would address the current misconceptions. Relating good rain season with successful tree planting among participants demonstrate a level of awareness on the need to conserve the environment and mitigate climate change. Withdrawal of maize farming in the drier IL6 should be seen as a realization that maize is not a viable venture in light of a changing climate. The choice of maize farming may have been informed by dietary preferences but persistent failure of the crop over the years may have gradually informed the decision to increase acreage of more drought-tolerant crops such as millet and green gram (Smucker and Wisner 2008). Overall, to improve knowledge on causes and impacts of climate change in Tharaka, will require scaling-up effort to use credible scientific institutions to communicate climate change science.

\section{Conclusion}

This paper has presented results of conceptual understanding of climate change and variability in Tharaka. FGDs and household survey were used to collect data from four main agro-ecological zones in Tharaka subcounty. People of Tharaka are aware of climate change and variability. This is reflected in frequent droughts and change in rainfall amount. Respondents associated 
climate change and variability with deforestation and industrial pollution, showing awareness on the role of man in altering the climate. This awareness should be harnessed into an opportunity to mitigate climate change. There are however misconceptions on the causes of climate change and variability. The paper recommends involvement of scientific institutions in communicating climate change science. Knowledge of determinants of climate variability and basic skills in data collection and descriptive statistics are a way of improving awareness of climate science among local communities in arid and semi-arid lands.

\section{Additional files}

Additional file 1. Focus group discussion data.

Additional file 2. Household survey data.

Additional file 3. Interview schedule for focus group discussion.

\begin{abstract}
Abbreviations
MAM: March-April-May; AEZ: agro-ecological zone; ENSO: El Niño southern oscillation; FGD: focus group discussion; IL: intermediate lowland; LM: lower midland; OND: October-November-December; ONDJ: October-November-December-January.
\end{abstract}

\section{Authors' contributions}

CWR: conceptualized and executed the research, drafted the manuscript GLM: supervisor to 1st author, played a major part in the improvement of the methods (sampling and data analysis), revised manuscript. CAS: supervisor to 1st author, played a major part in the improvement of literature review and discussion of results, revised manuscript. All authors read and approved the final manuscript.

\section{Authors' information}

Charles W. Recha has a Ph.D. in climatology. Research areas include rainfall variability, use of climate forecasts in decision-making, perception studies in climate change and climate variability and NDVI nexus. Currently a chair and lecturer of Geography, Egerton University. George L. Makokha has a Ph.D. in urban climatology. Research areas include urban climate studies, integrated watershed management. Currently a senior lecturer in Department of Geography, Kenyatta University. Chris A. Shisanya has a Ph.D. in agro-climatology. Research areas include climate variability and crop production, integrated watershed management, agro-forestry. Currently professor of Geography and Dean School of Humanities and Social Sciences.

\section{Author details}

1 Department of Geography, Egerton University, P. O. Box 536, Egerton 20115, Kenya. ${ }^{2}$ Department of Geography, Kenyatta University, P. O. Box 43844, Nairobi 00100, Kenya.

\section{Acknowledgements}

The authors acknowledge financial support from the African Climate Change Fellowship Programme a programme of International SysTem for Analysis, Research and Training (START) for a study fellowship award to the first author and fieldwork support from the EU Water Facility Project (No. 9 ACP RPR 50/11). We further acknowledge the valuable support of the Department of Arid Lands-Tharaka sub-county and the receptive people of Tharaka who participated in the survey, without which this study would not have been possible.

\section{Competing interests}

The authors declare that they have no competing interests.

\section{Availability of data and materials}

Attached is household survey data (refer to variables B6.2.1a-B6236c2) and FGD tool used in the study (applicable questions to this manuscript are in part C of the tool) - provided as Additional files 1, 2, 3. It's instructive to note here that data and results in this manuscript were derived from a PhD thesis of the first author (Recha 2013, Kenyatta University, unpublished).

\section{Consent for publication}

This is original work that has not been submitted anywhere for publication.

\section{Ethics approval and consent to participate}

Not applicable.

\section{Funding}

Eu Water Facility, Project No. 9 ACP RPS 50/11: a project of Siegen University, Germany and Kenyatta University. African Climate Change Fellowship (ACCFP), 2009/2010: a project of International System for Analysis, Research and Training (START), USA.

\section{Publisher's Note}

Springer Nature remains neutral with regard to jurisdictional claims in published maps and institutional affiliations.

Received: 23 January 2017 Accepted: 19 September 2017

Published online: 02 October 2017

\section{References}

Adimassu Z, Kessler A, Stroosnijder L (2014) Farmers strategies to perceived trends of rainfall and crop productivity in the central Rift Valley of Ethiopia". Environ Dev 11:123-140. doi:10.1016/j.envdev.2014.04.004

Becken S, Lama AK, Espiner S (2013) The cultural context of climate change impacts: perceptions among community members in the Annapurna conservation area, Nepal". Environ Dev 8:22-37. doi:10.1016/j. envdev.2013.05.007

Byg A, Salick J (2009) Local perspectives on a global phenomenon_climate change in Eastern Tibetan villages. Glob Environ Change 19:156-166. doi:10.1016/j.gloenvcha.2009.01.010

Camberlin P, Okoola RE (2003) The onset and cessation of the long rains in eastern Africa and their inter-annual variability. Theor Appl Climatol 75:43-54. doi:10.1007/s00704-002-0721-5

Fabeku BB, Okogbue EC (2014) Trends in vegetation response to drought in Sudao-Sahelian part of northern Nigeria. Atmos Clim Sci 4:569-588, doi:10.4236/acs.2014.44052

Gandure S, Walker S, Botha JJ (2013) Farmer's perceptions of adaptation to climate change and water stress in a South African rural community. Environ Dev 5:39-53. doi:10.1016/j.envdev.2012.11.004

Gioto L, Wandiga S, Oludhe C (2016) Climate change detection across all livelihood zones in Tharaka Nithi County. J Met Relat Stud 9:11-17. doi:10.20987/jmrs.2.08.2016

Hansen W (2005) Integrating seasonal climate prediction and agricultural models for insights into agricultural practice. Philos Trans R Soc B 360:2037-2047. doi:10.1098/rstb.2005.1747

Hansen J, Indeje M (2004) Linking dynamic seasonal climate forecasts with crop simulation for maize yield prediction in semi-arid Kenya. Agric For Meteorol 125:143-157. doi:10.1016/j.agrformet.2004.02.006

Hastenrath S, Polzin D, Camberlin P (2004) Exploring the predictability of the short rains at the coast of East Africa. Int J Climatol 24:1333-1343

Howe DP, Thaker J, Leiserowitz A (2014) Public perception of rainfall changes in India. Clim Change 127:211-225. doi:10.1007/s10584-014-1245-6

Hulme M (2008) Geographical work at the boundaries of climate change. Trans Inst Br Geogr 33:5-11

Jaetzold R, Schmidt H, Hornetz B, Shisanya C (2007) Farm management handbook of Kenya: part C, East Kenya, vol II, 2nd edn. Ministry of Agriculture, Nairobi

Kajembe GC, Julius F, Nduwamungu PW, Mtakwa PW, Nyange DA (2005) Impact of indigenous-based interventions on land conservation: a case study of soil conservation and agroforestry project, Arumeru District, Tanzania. Land Degrad Dev 16:311-325. doi:10.1002/ldr.656 
Kashaigili JJ, Levira P, Liwenga E, Mdemu MV (2014) Analysis of climate variability, perceptions and coping strategies of Tanzania's coastal forest dependent communities. Am J Clim Change 3:212-222

Kundezewicz ZW, Mata L, Arnel NW, Doll P, Jimenez B, Miller K, Oki T, Sen Z, Shiklomanov I (2008) The implication of projected climate change for freshwater resources and their management. Hydrol Sci 53(1):3-10

Leiserowitz AA (2005) American risk perceptions: is climate change dangerous? Risk Anal 25(6):1433-1442. doi:10.1111/j.1540-6261.2005.00690.x

Leonard S, Person M, Olawsky K, Kofod F (2013) The role of culture and traditional knowledge in climate change adaptation: insights from East Kimberly, Australia. Glob Environ Change 23:623-632. doi:10.1016/j. gloenvcha.2013.02.012

LiY (2015) The urban-rural disparities in public awareness of climate change in China: a study of outreach communication strategies. Int J Clim Change: Impacts Responses 8(1):11-19

Locatelli B (2011) Synergies between adaptation and mitigation in a nutshell. COBAM Brief. Centre for International Forestry Research (CIFOR), Bogor. doi: 10.17528/cifor/003619

Lorenzoni I, Pidgeon NF (2006) Public views on climate change: European and USA perspectives. Clim Change 77:73-95. doi:10.1007/sl0584-006-9072-z

Maddison DJ (2007) The perception of and adaptation to climate change in Africa. World bank policy research working paper no. 4308. http://ssrn. com/abstract $=1005547$

Mubaya CP, Njuki J, Mutsvangwa EP, Mugabe FT, Nanja D (2012) Climate variability and change or multiple stressors? Farmer perceptions regarding threats to livelihoods in Zimbabwe and Zambia. J Environ Manag 102:9-17

Mutai CC, Ward MN, Coleman AW (1998) Towards the prediction of the East Africa short rains based on sea surface temperature-atmospheric coupling. Int J Climatol 18:975-997

Mworia L, Ndiku JM (2012) Inter ethnic conflict in Kenya: a case of TharakaTigania conflict, causes, effects and intervention strategies. J Res Peace Gend Dev 2(7):162-170 (ISSN: 2251-0036). http://www.interesjournals. org/JRPGD

Opiyo F, Wasonga OV, Nyangito MM, Mureithi SM, Obando J, Munang R (2016) Determinants of perceptions of climate change and adaptation among Turkana pastoralists in northwestern Kenya. Clim Dev 8:179-189. doi:10.1 080/17565529.2015.1034231

Orindi VA, Ochieng A (2005) Case study 5 Kenya: seed fairs as a drought recovery strategy in Kenya. IDS Bull 36(4):87-102. doi:10.1111/j.1759-5436.2005. tb00236.x

Recha CW (2013) Effects of climate variability on water resources and livelihoods and state of adaptive capacity in semi-arid Tharaka district, Kenya, PhD thesis, Kenyatta University. http://ir-library.ku.ac.ke/handle/123456789/6952 (unpublished)

Recha CW, Makokha GL, Traore PS, Shisanya C, Lodoun T, Sako A (2012) Determination of seasonal rainfall variability, onset and cessation in semi-arid Tharaka district, Kenya. Theor Appl Climatol 108:479-494. doi:10.1007/ s00704-011-0544-3
Republic of Kenya (2010a) National climate change response strategy. http:// cdkn.org/wp-content/uploads/2012/04/National-Climate-ChangeResponse-Strategy_April-2010.pdf. Accessed 20 May 2016

Republic of Kenya (2010b) Population and housing census, 2009, vol 1a. The Kenya National Bureau of Statistics, Nairobi

Sanchez-Cortes MS, Chevero EL (2011) Indigenous perception of changes in climate variability and its relationship with agriculture in a Zoque community of Chiapas, Mexico. Clim Change 107:363-389. doi:10.1007/ s10584-010-9972-9

Seleshi Y, Zanke U (2004) Recent changes in rainfall and rainy days in Ethiopia. Int J Climatol 24:973-983. doi:10.1002/joc.1052

Shisanya CA (1996) Chances and risks of maize and bean growing in the semiarid areas of SE Kenya during the expected deficient, normal and above normal rainfall of the short rainy season (published doctoral thesis). Trier Universitet, Trier Germany

Silva CJ, Albernaz-Silveira R, Noguera PS (2014) Perceptions on climate change of the traditional community Cuiabá Mirim, Pantanal Wetland, Mato Grosso, Brazil. Clim Change 127:83-92. doi:10.1007/s10584-014-1150-z

Smucker T, Wisner B (2008) Changing household responses to drought in Tharaka, Kenya: vulnerability, persistence and challenge. Disasters 32(2):190-215. doi:10.1111/j.1467-7717.2007.01035.x

Tonnang H, Richard EZ, Kangalawe YM, Yanda, PZ (2010) Predicting and mapping malaria under climate change scenarios: the potential redistribution of malaria vectors in Africa. Malar J 9:1-10. http://www.malariajournal. com/content/9/1/111

Tscharkert P (2007) Views from the vulnerable: understanding climatic and other stressors in the Sahel. Glob Environ Change 17:381-396. doi:10.1016/j.gloenvcha.2006.11.008

van de Steeg JA, Herrero M, Kinyangi J, Thornton PK, Rao KPC, Stern R, Cooper $P$ (2009) The influence of current and future climate-induced risk on the agricultural sector in East and Central Africa: sensitizing the ASARECA strategic plan to climate change. International Livestock Research Institute, Nairobi

Vedwan N, Rhoades R (2001) Climate change in western Himalayas of India: a study of local perception and response. Clim Res 19:109-117. http:// www.jstor.org/stable/24866773. Accessed 18 Jul 2017

Washington R, Harrison M, Conway D, Black E, Challinor A, Grimes D, Jones R, Morse A, Kay G, Todd M (2006) Africa climate change: taking a shorter route. Am Meteorol Soc 87(10):1355-1366. doi:10.1175/BAMS-87-10-1355

Yasunaka S, Hanawa K (2005) Regime shift in the global sea surface temperatures: its relation to El niño-southern oscillation events and dominant variation modes. Int J Climatol 25:913-930. doi:10.1002/joc.1172

\section{Submit your manuscript to a SpringerOpen ${ }^{\circ}$ journal and benefit from:}

- Convenient online submission

- Rigorous peer review

- Open access: articles freely available online

- High visibility within the field

Retaining the copyright to your article

Submit your next manuscript at springeropen.com 